Original Research Paper

\title{
Green Synthesized Silver Nanoparticles Prepared from the Antimicrobial Crude Extracts of two Brown Seaweeds Against Plant Pathogens
}

\author{
Annakodi Jothirethinam, Sivanantham Prathiba, Nagarajan Shanthi and Kulanthaiyesu Arunkumar \\ Department of Botany, Alagappa Government Arts College (Alagappa University), \\ Karaikudi-630 003, Sivaganga Dt, Tamil Nadu, India
}

Article history

Received: 31-01-2015

Revised: 22-05-2015

Accepted: 28-06-2015

Corresponding Author:

Kulanthaiyesu Arunkumar

Department of Botany,

Alagappa Government Arts

College (Alagappa University),

Karaikudi-630 003, Sivaganga

Dt, Tamil Nadu, India.

Tel: 914565224521

Fax: 914565227497

E-mail: rsrnarun@gmail.com

\begin{abstract}
This study aimed for green synthesis of silver nanoparticles (Ag-NPs) from the antimicrobial crude extracted in chloroform: methanol( $1: 1 \mathrm{v} / \mathrm{v})$ from the two brown seaweeds Spatoglossum asperum and Hedophyllum sessile active against two pathogenic bacteria (Xanthomonas axonopodis pv. citri and X. oryzae pv. oryzae) and a fungus Ustilaginoidea virens cause diseases in plants under in vitro assay. Crude extracts exhibit high antibacterial activity and low antifungal activity. Green synthesized Ag-NPs showed very high antimicrobial properties on comparing its crude extracts. Among the crudes, extract of Spatoglossum asperum exhibits higher bioactivity than the extract of Hedophyllum sessile but Ag-NPs prepared from the extract of $H$. sessile possess very strong bioactivity over Ag-NPs of Spatoglossum asperum. Reduction of Ag-NPs was confirmed by UV spectra. FTIR data indicate that active groups related to terpenoids and phenols found in the crude extracts were responsible for the reduction of Ag-NPs. The XRD data showed that the pure three types of crystal silver structure at $2 \theta$ values $32.51,46.50$ and 74.62 corresponding to 111,200 and 220 planes for silver, respectively. This study concludes that chloroform: methanol $(1: 1 \mathrm{v} / \mathrm{v})$ extracts of Hedophyllum sessile and Spatoglossum asperum containing active groups related to terpenoids and phenols and they are acting as reducing agents for green synthesis of silver nanoparticles which are potential source for controlling the plant pathogens studied.
\end{abstract}

Keywords: Brown Seaweeds, Silver Nanoparticles, Antimicrobial Property-Plant Pathogens

\section{Introduction}

Nanotechnology is emerging as a rapidly growing field with its application in Science and Technology for the purpose of manufacturing new materials at the nanoscale level (Prabhu et al., 2010). The synthesis and characterization of nanoparticles is an important area of research as selection of size and shape of nanoparticles provides an efficient control over many of the physical and chemical properties and their potential application in optoelectronics, recording media, sensing devices, catalysis and medicine (Mazur, 2004). The current chemical methods for synthesizing nanoparticles are energy intensive; employ toxic chemicals which produce hazardous wastes that preclude them for any biomedical application. Conversely, the physical methods of nanoparticle synthesis such as sputter deposition, thin films etc., were often difficult to achieve. Therefore, there is a growing need for the uses of bio-compatible, non-toxic, cost-effective and eco-friendly methods for production of silver nanoparticles (Jae et al., 2009). Biological methods are considered safe and ecologically sound for the nanomaterial fabrication and alternative to conventional physical and chemical methods. Biological systems such as yeast, fungi, bacteria, plants etc., considered as biomimetics for the synthesis of nanostructures of biocompatible metal and semiconductors. Among the biological systems, the marine organisms are greatly deserved for the syntheses of different nanoparticles (Klaus et al., 1999; Nair and Pradeep, 2002; Konishi and Uruga, 2007) because of their diversity richness and high tolerance under ambient 
conditions of temperature, pressure and acidity. Innumerable organisms including algae, bacteria and fungi (Vigneshwaran et al., 2007) have already been harnessed for the green synthesis of silver nanoparticles. Marine macroalgae(seaweeds) have various unique phytochemicals including heteropolysaccharides, alkaloids, steroids, phenols, saponins and flavonoids flavonoids (Mansuya et al., 2010). Studies have assured that biomolecules like protein, phenols, flavonoids and some phytochemicals have the ability to reduce the ions to the nanosize and also play an important role in the capping of the nanoparticles for its stability (Vedpriya, 2010). Silver nanoparticles (Ag-NPs), is gaining greater demand due to the emergence of antibiotic-resistant pathogens (Goldmann et al., 1996). Metallic silver in the form of nanoparticles has made a remarkable response as a potential antimicrobial agent (Chastre, 2008). Silver components have been proven as an effective tool for retarding and preventing the microbial infections. In addition, silver is known to exhibit oligo dynamic effect because of its ability to exert inhibitory effect at minute concentrations (Tien et al., 2009).

Canker in citrus caused by the bacterium Xanthomonas axonopodis pv. citri reported to produce up to $70 \%$ yield loss (Graham et al., 2013). Estimated yield loss of bacterial blight caused by the bacterium Xanthomonas oryzae pv. oryzae in tropical regions was from 2 to $74 \%$ depending on location, season, weather conditions and cultivars (Reddy et al., 1979). A fungus Ustilaginoidea virens cause false smut disease in paddy and its infection usually low (1-10\%) or may increase to $50-60 \%$ in years and severe infection causing 50.3$75.4 \%$ empty grains (Li et al., 1986). Pesticidal agents of biological origin are advantageous one to control the pests as well as safe to environment. In this line, green synthesized Ag-NPs prepared from seaweeds have potential application in the biopesticides production. Works have been attempted on the green synthesis of Ag-NPs using higher plants (Gilaki, 2010; Khalil et al., 2014) and microalgae (Patel et al., 2015) but limited studies are made using marine macroalgae (seaweeds) (Govindaraju et al., 2009; Kumar et al., 2013). In this study, crude extracts prepared from the two brown seaweeds showing antimicrobial activity were used for green synthesis of Ag-NPs against plant pathogens.

\section{Materials and Methods}

\section{Seaweed Collection and Preparation of Crude Extract}

Live and healthy specimens brown seaweeds such as Hedophyllum sessile (C. Agardh) SetchellPuthumadam $\quad\left(9^{\circ} 16^{\prime} 47^{\prime} \mathrm{N}, \quad 79^{\circ} 7^{\prime} 12^{\prime \prime} \mathrm{E}\right)$ and Spatoglossum asperum J. Agardh-Thiruchendur $\left(8.4833^{\circ} \mathrm{N}, 78.1167^{\circ} \mathrm{E}\right)$ were collected along the coast of Gulf of Mannar, India during January 2014. The samples were washed thoroughly in seawater followed by tap water and immediately air-dried under shade at room temperature for 7 days, chopped, pulverized and stored in desiccators till further study.

For the preparing the crude extract, $50 \mathrm{~g}$ of pulverized sample of seaweed was soaked in $100 \mathrm{~mL}$ of chloroform: methanol $(1: 1 \mathrm{v} / \mathrm{v})$ using $250 \mathrm{~mL}$ conical flask and kept under dark for 10 days at $27^{\circ} \mathrm{C}$. The extraction was repeated thrice. Then the extracted crudes were combined and concentrated using rotavapour under reduced pressure at $45^{\circ} \mathrm{C}$. The concentrated crude extract was weighed and stored at $0^{\circ} \mathrm{C}$ till further study.

\section{Green Synthesis of Ag-NPs (Song and Kim, 2008)}

A portion of crude extract of each seaweed weighing $0.1 \mathrm{~g}$ was dissolved with $3 \mathrm{~mL}$ distilled $\mathrm{H}_{2} \mathrm{O}$ and a same amount of $\mathrm{AgNO}_{3}\left(1 \times 10^{1} \mathrm{M}\right)$ and stirred the extract well at room temperature $\left(25^{\circ} \mathrm{C}\right)$. Then the solution was incubated in dark at $37^{\circ} \mathrm{C}$ under static condition for observing colour change. A control setup was also maintained without crude extract. The mixture was then centrifuged at $5000 \mathrm{rpm}$ for $20 \mathrm{~min}$ and pellets containing crude silver nanoparticles were collected. Aqueous pellet was freeze dried and stored at $0^{\circ} \mathrm{C}$ till further study.

\section{Antimicrobial Activities of Crude Extracts and Green Synthesized Ag-NPs}

Antimicrobial potential of crude extracts and green synthesized Ag-NPs was evaluated using two bacteria and a fungus cause diseases in plants. The pathogenic bacteria, Xanthomonas axonopodis pv. citri (Hasse) Vauterin et al. AGACA 01 cause citrus canker and Xanthomonas oryzae pv. oryzae (Ishyama) Dye AGACA 02 cause blight in paddy. The fungus Ustilaginoidea virens (Cooke) Takah AGACF 01 cause false smut in paddy. The test pathogens available in the Botany Research Laboratory of Alagappa Government Arts Science College, Karaikudi were used for antimicrobial assay. Sterile $5.0 \mathrm{~mm}$ diameter Whatman \# 1 paper discs loaded with $50 \mu \mathrm{l}$ of 25,50 and $100 \mu \mathrm{g}$ of crude seaweed extracts and green synthesized Ag-NPs were dried aseptically and impregnated on Petri plates for antimicrobial assay.

For antibacterial Assay (Arunkumar and Rengasamy, 2000), agar diffusion technique using $100 \mathrm{~mm}$ diameter Petri plates containing Ca. $20 \mathrm{~mL}$ of $1.5 \%$ nutrient agar medium (g L ${ }^{1}$, Peptone -10, Beef extract-10, NaCl- 5, Agar-15, in distilled $\mathrm{H}_{2} \mathrm{O}, \mathrm{pH}-7.0$ ) smeared with 0.05 $\mathrm{mL}$ of bacterial culture in exponential phase of $1.0 \mathrm{OD}$ at $590 \mathrm{~nm}$ were incubated at $27^{\circ} \mathrm{C}$.

For antifungal assay (Suvega and Arunkumar, 2014), Petri plates were seeded ca. $10 \mathrm{~mL}$ of $3 \%$ Potato Dextrose Agar (PDA) (g L ${ }^{1}$, Potato-200, dextrose- 20, 
agar-30, in distilled water, $\mathrm{pH}$ 5.6). A loop full of fungal mycelia mixed evenly with $10 \mathrm{~mL}$ of $1.5 \%$ PDA was poured over preseeded 3\% PDA plates and incubated at $25^{\circ} \mathrm{C}$. Antibacterial and antifungal activities were measured after $48 \mathrm{~h}$ of incubation.

The diameter of agar clear zone around the disc as result of diffusion of active substances was measured millimeters as antibacterial/antifungal activity. The solvents used for reconstituting the substances loaded on the paper discs were treated as solvent control did not show any bioactivity. Triplicates were maintained in each experiment and mean value expressed.

\section{Characterization of AgNPs}

Freeze dried AgNPs prepared from both seaweeds were recorded in UV spectra between 200 to $600 \mathrm{~nm}$ (Gajbhiye et al., 2009). FT-IR spectroscopy (Spectrum RX I, Perkin-Elmer) was recorded by KBR pellet method in the spectral range of 4000 to $400 \mathrm{~cm}^{1}$ to identify the biomolecules responsible for the reduction of the Ag+ ions and capping material of synthesized AgNPs. For comparison, crude seaweed extracts were also recorded FT-IR spectroscopy. For XRD diffraction (Chandran et al., 2006), Ag-NPs were measured using $\mathrm{X}$-ray diffractometer (PXRD-6000 SCHIMADZU) in the angle range of $10^{\circ} \mathrm{C}-80^{\circ} \mathrm{C}$ at $2 \theta$, scan axis: $2: 1$ sym. The size of the Ag-NPs was calculated from the PXRD peak positions using Bragg's law.

\section{Results and Discussion}

\section{Antimicrobial Activity of Crude Extracts}

Crude extracts prepared from various solvents and methods from different species of seaweeds displayed wide range antimicrobial properties against human and plant pathogens (Arunkumar et al., 2010). Extracts prepared in chloroform: methanol $(1: 1 \mathrm{v} / \mathrm{v})$ from the brown seaweeds posses polar compounds exhibit bioactivity against plant pathogenic bacteria (Arunkumar and Rengasamy, 2000) and the efficacy of crude is not as equal to commercial antibiotic, streptomycin sulphate used to control canker in citrus and blight in paddy (Arunkumar et al., 2013). In this present study, crude extracts obtained in chloroform: methanol $(1: 1 \mathrm{v} / \mathrm{v})$ of two brown seaweeds Hedophyllum sessile and Spatoglossum asperum exhibit antimicrobial activities which was increased with increasing concentration of extracts (Fig. 1). Studies so far conducted on antimicrobial screening of seaweeds against plant pathogens showed investigation in this two brown seaweeds Hedophyllum sessile and Spatoglossum asperum are not yet made (Arunkumar et al., 2010; 2013). This study found that antibacterial activity of the crude extracts was higher than antifungal activity and crude extracts of Spatoglossum asperum exhibits more bioactivity (Fig. 1 and 2) than the extract of Hedophyllum sessile (Fig. 1 and 3).

\section{Antimicrobial Activity of Green Synthesized Ag- NPs}

Recent works have proved that green synthesized silver nanoparticals exhibit potential broad-spectrum of antimicrobial activities (Gajbhiye et al., 2009; Govindaraju et al., 2009). Green synthesized silvernanoparticles prepared from extracts of plants including algae possessing antimicrobial properties tested against human and plant pathogens (Mohandass et al., 2013; Kumar et al., 2013; Paulkumar et al., 2014). Crude extracts showing antimicrobial activity are natural, less expensive and environmental safe hence in this study crude extracts obtained from the Hedophyllum sessile and Spatoglossum asperum were used as reducing agents to produce silver nanoparticles through green synthesis. Ironically antimicrobial activity of biosynthesized AgNPs prepared from the crude extracts of both seaweeds Hedophyllum sessile and Spatoglossum asperum was remarkably higher than the potential of crude extracts (Fig. 1). It was further observed that the Ag-NPs prepared from Hedophyllum sessile showed higher bioactitivty than Spatoglossum asperum (Fig. 2-4), however chloroform: methanol $(1: 1 \mathrm{v} / \mathrm{v})$ extracts both seaweeds Hedophyllum sessile and Spatoglossum asperum are the potential reducing agents for green synthesis of silver nanoparticles as source for preparing biopesticides to control the plant pathogens.

\section{Characterization of Ag-NPs by UV, FTIR and XRD Study}

Maximum absorption at $400 \mathrm{~nm}$ in the UV spectroscopy characteristics of Silver nanoparticles (Mohandass et al., 2013) was recorded in Hedophyllum sessile (Fig. 5) and Spatoglossum asperum (Fig. 6). FTIR spectra data is commonly used for identifying biomolecule responsible for the reduction of $\mathrm{Ag}^{+}$ions and the capping of the bioreduced Ag-NPs (Li et al., 2007; Song et al., 2009; Travan et al., 2009; Vanmathiselvi and Sivakumar, 2012). FTIR spectral peaks of Ag-NPs were strong and of crude were weak in Hedophyllum sessile (Fig. 7) as well as Spatoglossum asperum (Fig. 8). As earlier study (Vanmathiselvi and Sivakumar, 2012 ), in the FTIR spectra, a strong peak in the crude and a weak peak in the Ag-NPs recorded near $2900 \mathrm{~cm}^{-1}$ in Hedophyllum sessile (Fig. 7) and 2985 $\mathrm{cm}^{1}$ in Spatoglossum asperum (Fig. 8) were assigned to N-H stretching of alkaline. A band at $1600 \mathrm{~cm}^{1}$ in both spectra corresponds to primary amines (Vanmathiselvi and Sivakumar, 2012; Sahayaraj et al., 2012). A peak at $1230 \mathrm{~cm}^{1}$ corresponds to $\mathrm{C}-\mathrm{O}$ stretching of aromatic ethers exclusively present in the Ag-NPs of Spatoglossum asperum. 


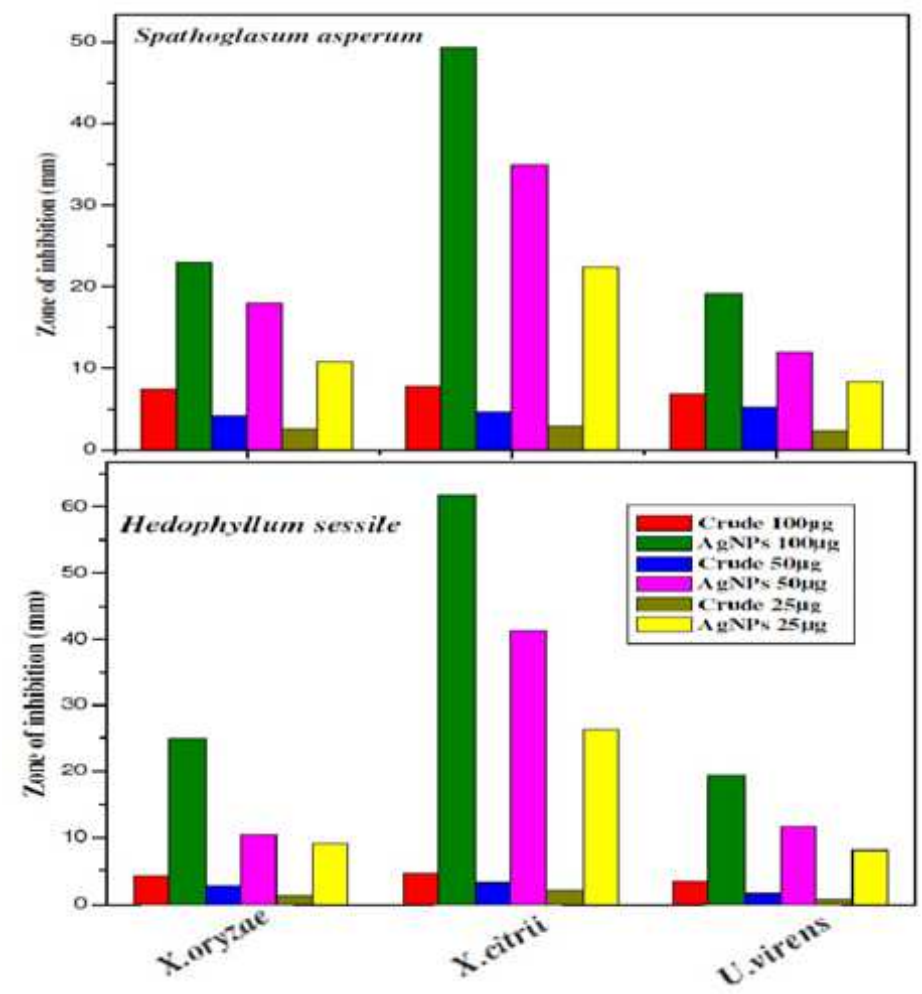

Fig.1. Antibacterial(X.oryzae and X.citri) and antifungal (U.virens) activities of different concentrations of crude extract and green synthesized Ag-Nps prepared from the chloroform: methanol (1:1 v/v) of Hedophyllum sessile and Spathoglossum asperum

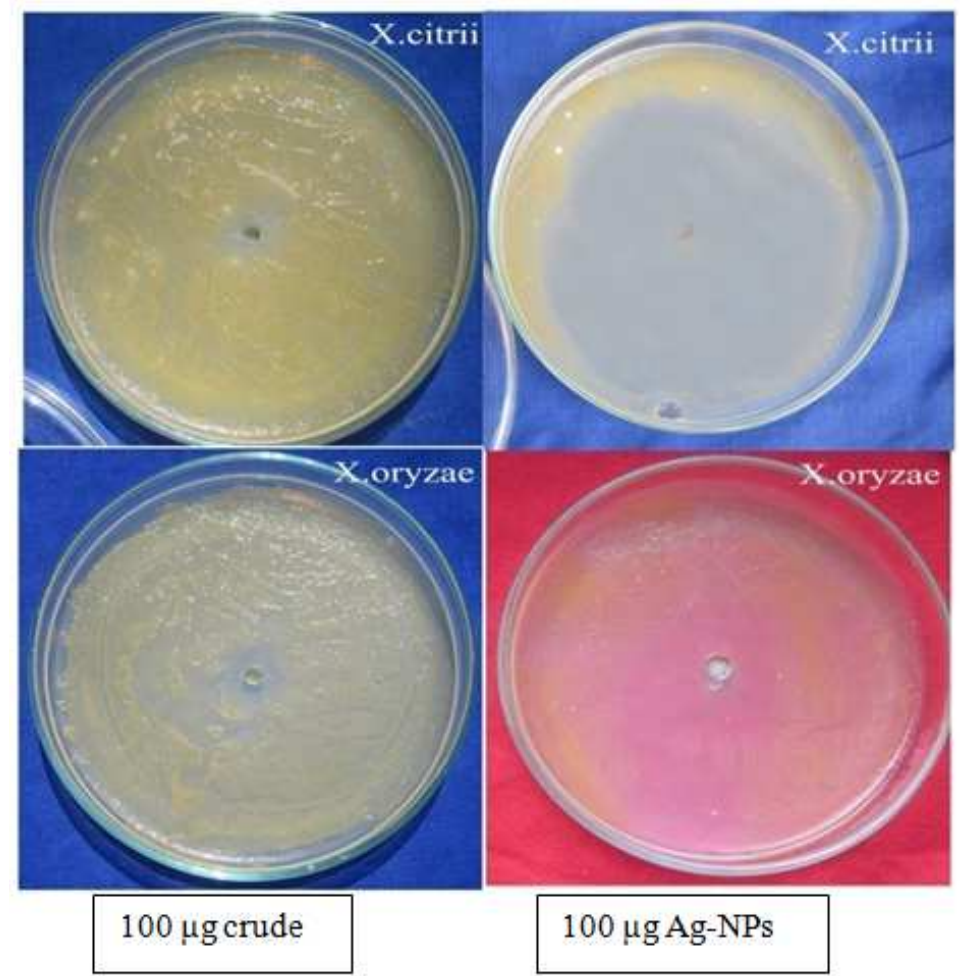

Fig. 2. Antibacterial activity of crude extract and green synthesized Ag-NPs obtained from the Spathoglossum asperum 


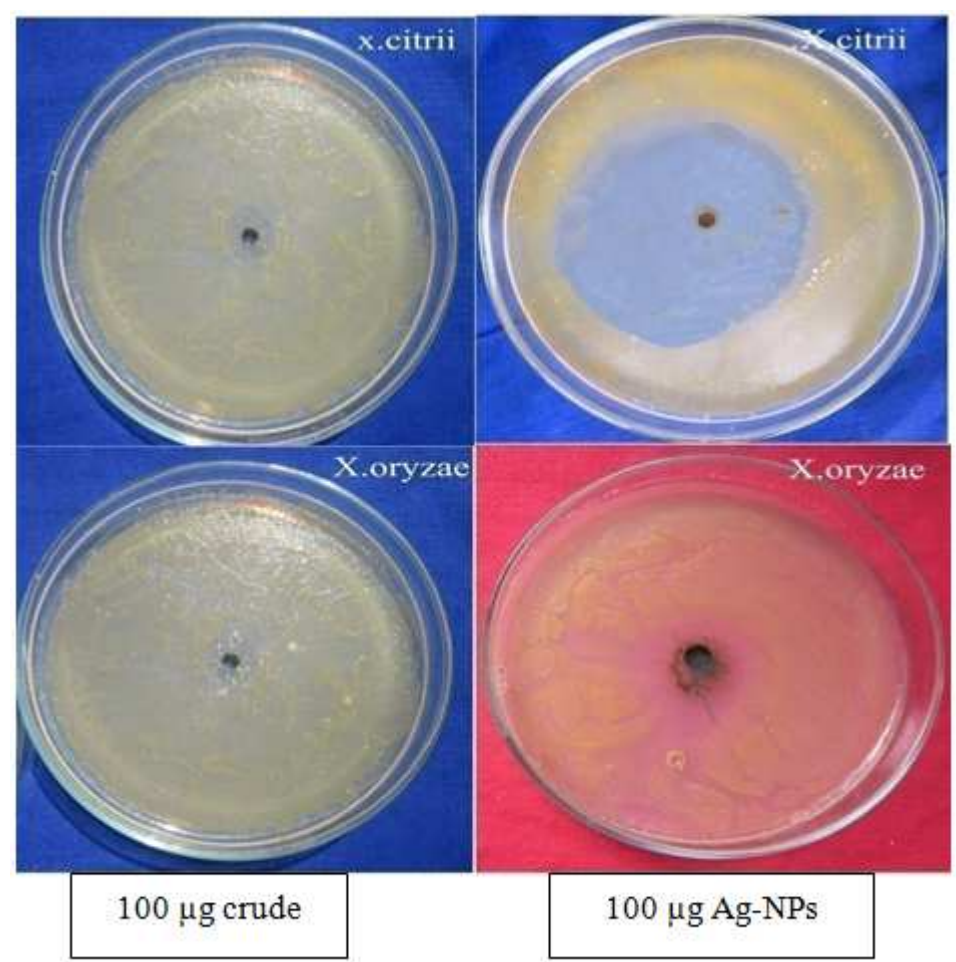

Fig. 3. Antibacterial activity of crude extract and green synthesized Ag-NPs obtained from the Hedophyllum sessile

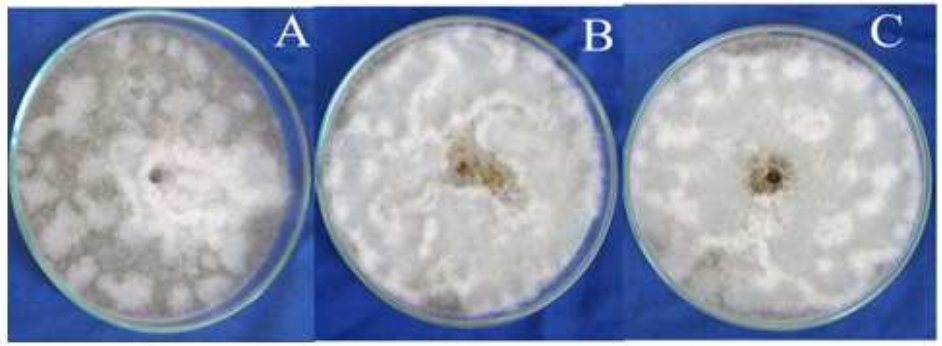

Fig. 4. Antifungal activity of crude extract of Spathoglossum asperum (A) green synthesized Ag-NPs of Spathoglossum asperum (B) and Hedophyllum sessile (C)

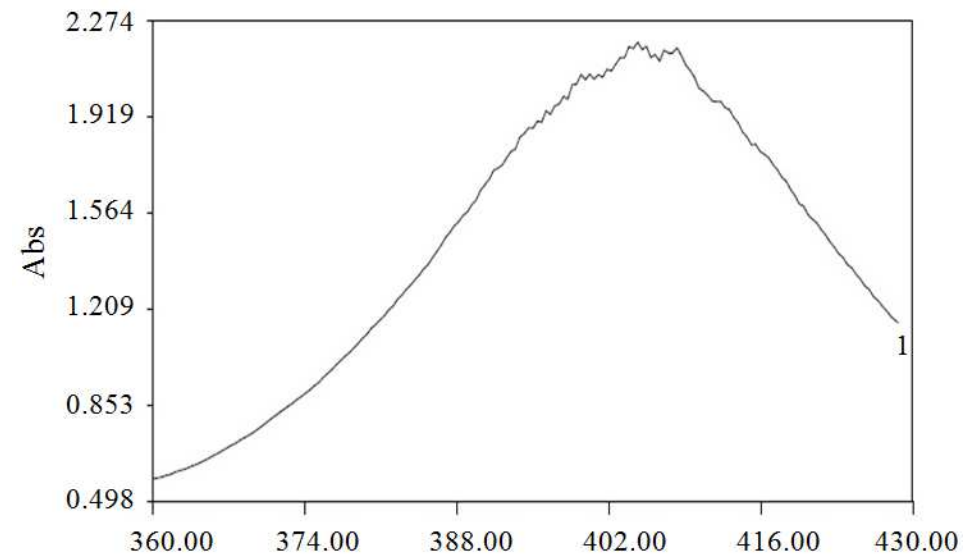

Fig. 5. UV spectrum of green synthesized AgNPs prepared from the chloroform: methanol (1:1 v/v) extract of Hedophyllum sessile 


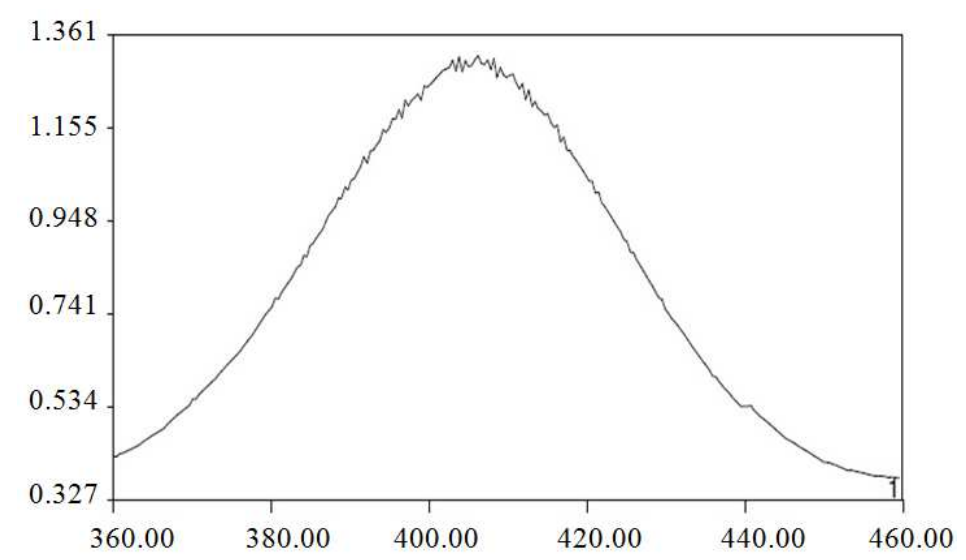

Fig. 6. UV spectrum of green synthesized Ag-NPs prepared from the chloroform: methanol (1:1 v/v) extract of Spathoglassum asperum

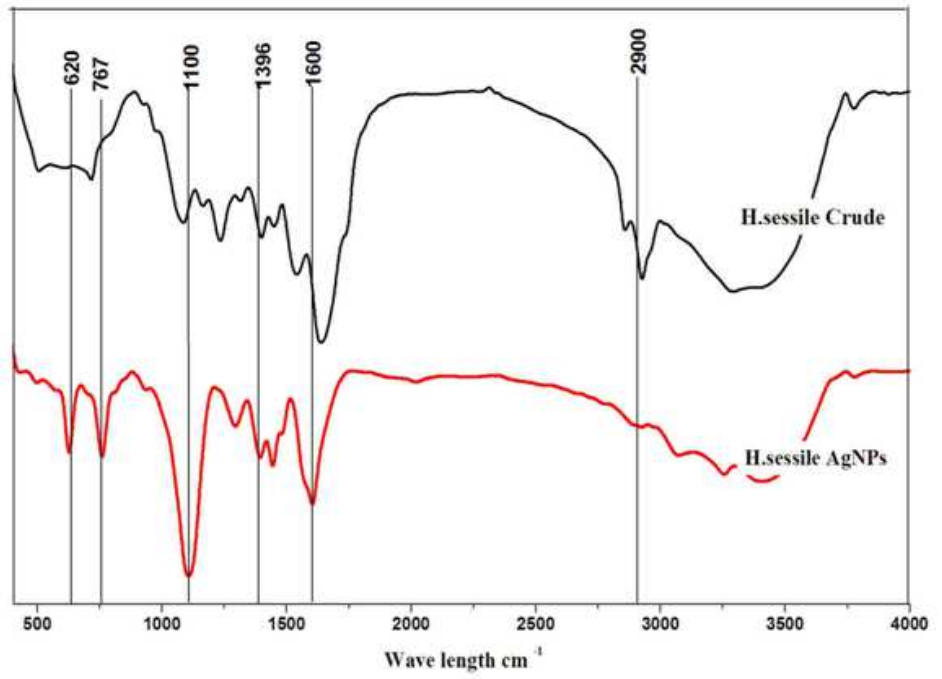

Fig. 7. FTIR spectroscopy of crude and green synthesized Ag-NPs prepared from the Hedopyllum sessile

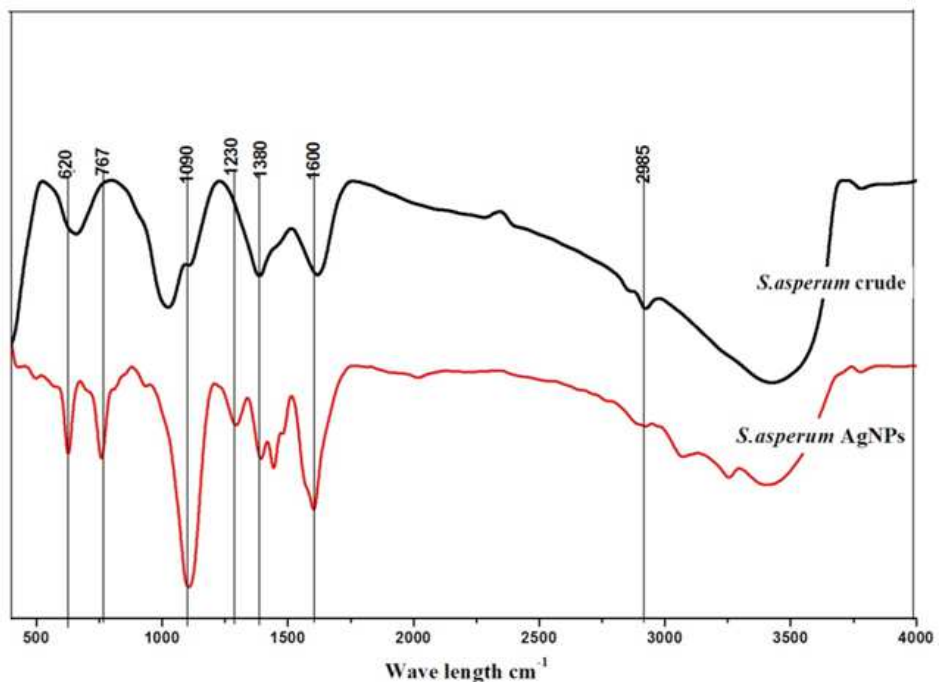

Fig. 8. FTIR spectroscopy of crude and green synthesized Ag-NPs prepared from the Spathoglossum asperum 
A strong peaks at $1100 \mathrm{~cm}^{1}$ and $1090 \mathrm{~cm}^{1}$ in Hedopyllum sessile and Spatoglossum asperum, respectively corresponds to $\mathrm{C}-\mathrm{N}$ stretching of the aliphatic amine, which is commonly found in protein, indicating protein as ligands for Ag-NPs, which increase the stability of nanoparticles synthesized (Shetty et al., 2006). Peaks at $620 \mathrm{~cm}^{1}$ and $767 \mathrm{~cm}^{1}$ in Ag-NPs of both seaweeds were assigned to the $\mathrm{C}-\mathrm{X}$ stretching of either chloroalkanes or bromoalkanes (Anil Kumar et al., 2007). These FTIR data indicate functional groups in the secondary metabolites such as phenols and terpenoids found in the crude extracts of Hedopyllum sessile and Spatoglossum asperum are the source of reducing agents for synthesis of Ag-NPs (Shetty et al., 2006).

The biosynthesized Ag-NPs was further structurally characterized through peaks observed in the XRD pattern. The sharp diffraction pattern of the XRD spectra obtained by the annealing at $200^{\circ} \mathrm{C}$ indicates a pure crystalline silver structure (Fig. 9 and 10). The XRD peaks at $2 \theta$ values of 32.51, 46.50 (for both seaweeds) and 64.62 (Hedopyllum sessile) corresponding to hkl values of 111 , 200 and 220 for planes of silver nano particles, respectively. All diffraction peaks correspond to the characteristic face centered cubic phase of silver nanoparticles (JCPDS No. 04-0783; Anil Kumar et al., 2007).

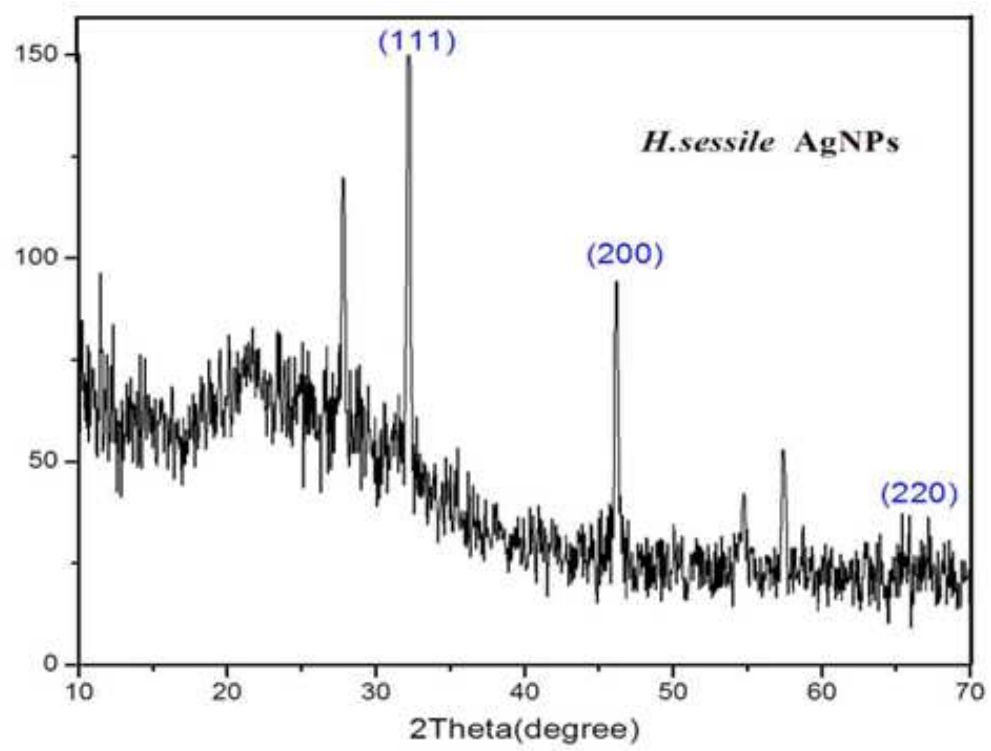

Fig. 9. XRD pattern of green synthesized Ag-NPs prepared from the chloroform: methanol (1:1 v/v) extract of Hedophyllum sessile

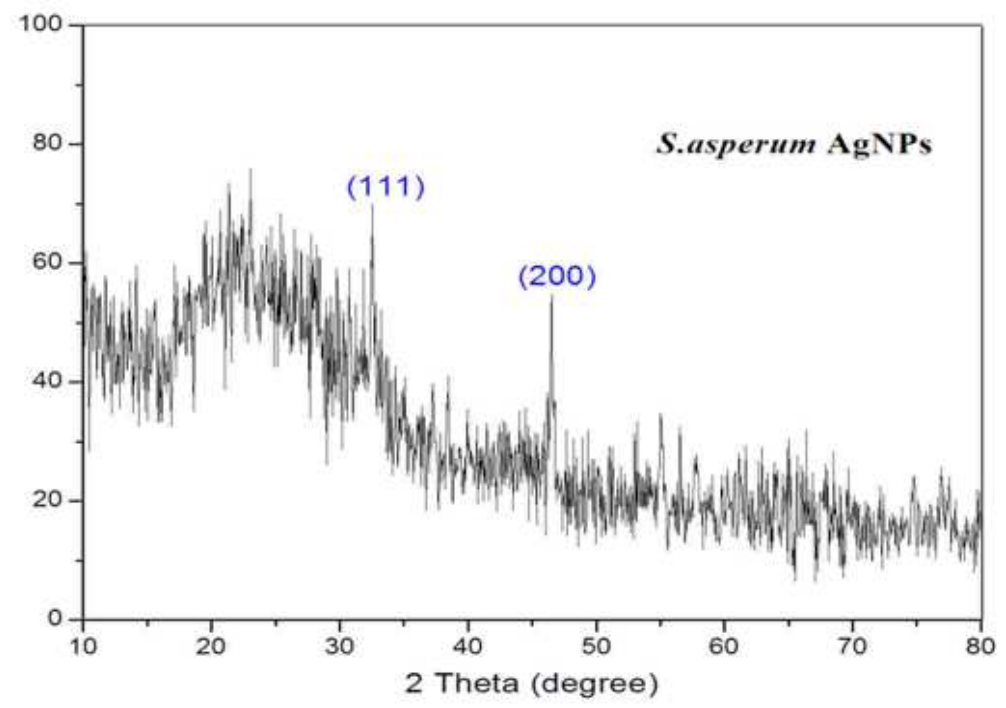

Fig. 10. XRD pattern of green synthesized Ag-NPs prepared from the chloroform: methanol (1:1 v/v) extract of Spathoglossum asperum 


\section{Conclusion}

This study concludes that crude extracts obtained in chloroform: methanol $(1: 1 \mathrm{v} / \mathrm{v})$ from the brown seaweeds Hedophyllum sessile and Spatoglossum asperum exhibit antimicrobial property against certain plant pathogens. These antimicrobial crude substances contain active groups related to terpenoids and phenols which are responsible for reducing silver nano particles. Bioactivity and XRD data support Hedopyllum sessile was more promising than Spatoglossum asperum for synthesizing silver nano particles.

\section{Acknowledgement}

This work was supported by the grant for Post graduate dissertation awarded by Tamil Nadu State Council for Higher Education (TANSCHE), Chennai, India.

\section{Author's Contributions}

Annakodi Jothirethinam: Carried out the experimental works of this finding.
Sivanantham Prathiba: Carried out the experimental works of this finding.

Natarajan Shanthi: Carried out analysis of the samples, prepared the data and figures suite to article and contribute writing part of the paper.

Kulanthaiyesu Arunkumar: Mentor who design the research problem with aim and objectives and supervised the experiment and contributed writing part of the article as well.

\section{Ethics}

This research article is original work which is not published earlier. The corresponding author aware and confirmed that all the others have read and approved the article and no ethical issue involved.

\section{References}

Anil Kumar, S., M.K. Abyaneh, S.W. Gosavi Sulabha, A. Ahmad and M.I. Khan, 2007. Nitrate reductasemediated synthesis of silver nanoparticles from $\mathrm{AgNO}_{3}$. Biotechnol. Lett., 29: 439-445.

DOI: $10.1007 / \mathrm{s} 10529-006-9256-7$

Arunkumar, K. and K. Rengasamy, 2000. Evaluation of antibacterial potential of seaweeds occurring along the coast of Tamil Nadu, India against the plant pathogenic bacterium, Xanthomonasoryzaepv. oryzae (Ishiyama) Dye. Botanica Marina, 43: 409-415.

Arunkumar, K., S.R. Sivakumar and N. Shanthi, 2013. Antibacterial potential of Gulf of Mannar seaweeds extracts against two plant pathogenic bacteria Xanthomonas axonopodis pv. citri (Hasse) Vauterin et al. and Xanthomonas campestris pv. malvacearum (Smith 1901) Dye. Int. J. Advances Pharmacy, Biology Chemistry, 2: 25-31.

Arunkumar, K., S.R. Sivakumar and R. Rengasamy, 2010. Review on bioactive potential in seaweeds (marine macroalgae): A special emphasis on bioactivity of seaweeds against Plant Pathogens. Asian J. Plant Sci., 9: 227-240.

Chandran, S.P., M. Chaudhary, R. Pasricha, A. Ahmad and M. Sastry, 2006. Synthesis of gold nanotriangles and silver nanoparticles using Aloevera plant extract. Biotechnol. Prog., 22: 577-583. DOI: $10.1021 / \mathrm{bp} 0501423$

Chastre, J., 2008. Evolving problems with resistant pathogens. Clin. Microbiol. Infect., 14: 3-14. DOI: $10.1111 / \mathrm{j} .1469-0691.2008 .01958 . x$

Gajbhiye, M., J. Kesharwani, A. Ingle, A. Gade and M. Rai, 2009. Fungus-mediated synthesis of silver nanoparticles and their activity against pathogenic fungi in combination with fluconazole, Nanomedicine: Nanotechnol. Biol. Med., 5: 382-386. DOI: 10.1016/j.nano.2009.06.005

Gilaki, M., 2010. Biosynthesis of silver nanoparticles using plant extracts. J. Biol. Sci., 10: 465-467.

Goldmann, D.A., R.A. Weinstein, R.P. Wenzel, O.C. Tablan and R.J. Duma et al., 1996. Strategies to prevent and control the emergence and spread of antimicrobial-resistant microorganisms in hospital. A challenge to hospital leadership. J. Am. Med. Assoc., 275: 234-240.

DOI: 10.1001/jama.1996.03530270074035

Govindaraju, K., V. Kiruthiga, V. Ganesh Kumar and G. Singaravelu, 2009. Extracellular synthesis of silver nanoparticles by a marine alga, Sargassum wightii, Grevilli and their antibacterial effects. J. Nanosci. Nanotechnol., 9: 5497-5501. DOI: 10.1166/jnn.2009.1199

Graham, J., B. Gruber and C. Bock, 2013. Integrated management of citrus canker. Citrus Industry.

Jae, Y.S. and S.K. Beom, 2009. "Rapid biological synthesis of silver nanoparticles using plant leaf extracts. Bioprocess Biosyst. Eng., 32: 79-84. DOI: $10.1007 / \mathrm{s} 00449-008-0224-6$

Khalil, M.M.H., E.H. Ismail, Z. Khaled, E. Baghdady and D. Mohamed, 2014. Green synthesis of silver nanoparticles using olive leaf extract and its antibacterial activity. Arabian J. Chemistry. 7: 1131-1139. DOI: 10.1016/j.arabjc.2013.04.007

Klaus, T., R. Joerger, E. Olsson and C.G. Granqvist, 1999. Silver-based crystalline nanoparticles, microbially fabricated. J. Proc. Natl. Acad. Sci. USA, 96: 13611-13614. DOI: 10.1073/pnas.96.24.13611

Konishi, Y. and T. Uruga, 2007. "Bioreductive deposition of platinum nanoparticles on the bacterium Shewanella algae. J. Biotechnol., 128: 648-653. DOI: 10.1016/j.jbiotec.2006.11.014 
Kumar, P., S.S. Selvi and M. Govindaraju. 2013. Seaweed-mediated biosynthesis of silver nanoparticles using Gracilaria corticata for its antifungal activity against Candida spp. Applied Nanoscience, 3: 495-500.

Li, S., Y. Shen, A. Xie, X. Yu and L. Qiu et al., 2007. Green synthesis of silver nanoparticles using Capsicum annuum L. extract. Green Chem., 9: 852-858. DOI: $10.1039 / \mathrm{B} 615357 \mathrm{G}$

Li, Y.G., B.J. Kang, B.D. Zhang, H.Z. Zeng and K.X. Xie et al., 1986. A preliminary study on rice false smut. Guangdong Agric. Sci., 4: 45-47.

Mansuya, P., P. Aruna, S. Sridhar, J.S. Kumar and S. Babu, 2010. Antibacterial activity and qualitative phytochemical analysis of selected seaweeds from Gulf of Mannar Region. J. Exp. Sci., 1: 23-26.

Mazur, M., 2004. Electrochemically prepared silver nanoflakes and nanowires. Electrochemistry Commun., 6: 400-403.

DOI: $10.1016 /$ j.elecom.2004.02.011

Mohandass, C., A.S. Vijayaraj, R. Rajasabapathy, S. Satheeshbabu and S.V. Rao et al., 2013. Biosynthesis of silver nanoparticles from marine seaweed Sargassum cinereum and their antibacterial activity. Indian J. Pharm. Sci., 75: 606-610.

Nair, B and T. Pradeep, 2002. Coalescence of nanoclusters and formation of submicron crystallites assisted by Lactobacillus Strains. Cryst. Growth Des., 2: 293-298. DOI: 10.1021/cg0255164

Patel, V., D. Berthold, P. Puranik and M. Gantar, 2015. Screening of cyanobacteria and microalgae for their ability to synthesize silver nanoparticles with antibacterial activity. Biotechnol. Reports, 5: 112-119. DOI: 10.1016/j.btre.2014.12.001

Paulkumar, K., G. Gnanajobitha, M. Vanaja, S. Rajeshkumar and C. Malarkodi et al., 2014. Piper nigrum leaf and stem assisted green synthesis of silver nanoparticles and evaluation of its antibacterial activity against agricultural plant pathogens. Scientific World J., DOI: 10.1155/2014/829894

Prabhu, N., T.R. Divya and G. Yamuna, 2010. Synthesis of silver phyto nanoparticles and their antibacterial efficacy. Digest. J. Nanomater. Biostruct., 5: 185-189.

Reddy, A.P.K., D.R. Mackenzie, D.I. Rouse and A.V. Rao, 1979. Relationship of bacterial leaf blight severity to grain yield of rice. Phytopathology, 69: 967-969.
Sahayaraj, K., S. Rajesh and J.M. Rathi, 2012. Silver nanoparticles biosynthesis using marine alga Padina pavonica (Linn.) and its microbicidal activity, Digest J. Nanomaterials Biostructures, 7: 1557-1567.

Shetty, G., C. Kedall, N. Shepherd, N. Stone and H. Barr, 2006. Raman spectroscopy: Elucidation of biochemical changes in carcinogenesis of oesophagus. Brit. J. Cancer., 94: 1460-1464. DOI: 10.1038/sj.bjc.6603102

Song, J.Y. and B.S. Kim, 2008. Biological synthesis of bimetallic $\mathrm{Au} / \mathrm{Ag}$ nanoparticles using Persimmon (Diopyros kaki) leaf extract. Korean J. Chem. Eng., 25: 808-811. DOI: 10.1007/s11814-008-0133-z

Song, K.C., S.M. Lee, T.S. Park and B.S. Lee, 2009. Preparation of colloidal silver nanoparticles by chemical reduction method. Korean J. Chem. Eng., 26: 153-155. DOI: 10.1007/s11814-009-0024-y

Suvega, T. and K. Arunkumar, 2014. Antimicrobial activity of bacteria associated with seaweeds against plant pathogens on par with bacteria found in seawater and sediments. British Microbiol. Res. J., 4: 841-855. DOI: 10.9734/BMRJ/2014/8678

Tien, D., K. Tseng, C. Liao and T. Tsung, 2009. Identification and quantification of ionic silver from colloidal silver prepared by electric spark discharge system and its antimicrobial potency study. J. Alloy Compd., 473: 298-302.

DOI: $10.1016 /$ j.jallcom.2008.05.063

Travan, A., C. Pelillo, I. Donati, E. Marsich and M. Benincasa et al., 2009. Non-cytotoxic silver nanoparticle-polysaccharide nanocomposites with antimicrobial activity. Biomacromolecules, 10: 1429-1435.

Vanmathiselvi, K. and T. Sivakumar, 2012. Isolation and characterization of silver nanoparticles from Fusarium oxysporum. Int. J. Curr. Microbiol. App. Sci., 1: 56-62.

Vedpriya, A., 2010. Living Systems: Eco-friendly nanofactories. Dig. J. Nanomater. Bios., 5: 9-21.

Vigneshwaran, N., N.M. Ashtaputre, P.V. Varadarajan, R.P. Nachane and K.M. Paraliker et al., 2007. Biological synthesis of silver nanoparticles using the fungus Aspergillus flavus. Mater. Lett., 61: 1413-1418. DOI: 10.1016/j.matlet.2006.07.042 